\title{
HUMAN PAPILLOMAVIRUS STATUS AND CERVICAL ABNORMALITIES IN WOMEN FROM PUBLIC AND PRIVATE HEALTH CARE IN RIO DE JANEIRO STATE, BRAZIL
}

Ledy H.S. OLIVEIRA(1), Maria L.G. ROSA(2), Claudia R.N. PEREIRA(1), Gentil A.L.B.M. VASCONCELOS(1), Roberta A. SILVA(1), Tomás Z. BARRESE(1), Maria O.O. CARVAlHO(1), Gabriela M. ABIB ABI(1), Eliana M. RODRIGUES(3) \& Silvia M.B. CAVALCANTI(1)

\begin{abstract}
SUMMARY
This article reports the HPV status and cervical cytological abnormalities in patients attended at public and private gynecological services from Rio de Janeiro State. It also comments the performance of each HPV DNA tests used. A set of 454 women from private health clinics was tested by routine Capture Hybrid II HPV DNA assay. Among these, 58.4\% presented HPV and nearly $90 \%$ of them were infected by high risk HPV types. However, this group presented few premalignant cervical lesions and no invasive cervical cancer was registered. We also studied 220 women from low income class attended at public health system. They were HPV tested by polymerase chain reaction using My09/11 primers followed by HPV typing with E6 specific primers. The overall HPV prevalence was $77.3 \%$. They also showed a high percentage of high squamous intraepithelial lesion-HSIL (26.3\%), and invasive cervical carcinoma (16.3\%). HPV infection was found in $93.1 \%$ and $94.4 \%$ of them, respectively. The mean ages in both groups were 31.5 and 38 years, respectively. In series 1, HPV prevalence declined with age, data consistent with viral transient infection. In series 2, HPV prevalence did not decline, independent of age interval, supporting not only the idea of viral persistence into this group, but also regional epidemiological variations in the same geographic area. Significant cytological differences were seen between both groups. Normal and benign cases were the most prevalent cytological findings in series 1 while pre-malignant lesions were the most common diagnosis in the series 2 . HPV prevalence in normal cases were statistically higher than those from series $1(\mathrm{p}<0.001)$, indicating a higher exposure to HPV infection. Women from both samples were referred for previous abnormal cytology. However, socio-demographic evidence shows that women from series 1 have access to treatment more easily and faster than women from series 2 before the development of pre-malignant lesions. These data provides baseline support for the role of social inequalities linked to high risk HPV infection leading to cervical cancer. Broadly screening programs and the development of safe and effective vaccines against HPV would diminish the toll of this disease that affect mainly poor women.
\end{abstract}

KEYWORDS: Human papillomavirus; PCR; Hybrid capture; Cervical intraepithelial neoplasias; Socioeconomic factors.

\section{INTRODUCTION}

Many human and animal papillomaviruses occur under latent status and they can be detected on the health skin $^{2}$. Human papillomavirus (HPV) infection are largely transient, usually asymptomatic and most of them without clinical consequence. In some countries $20-40 \%$ of sexually active young women have detectable HPV genital infection and the prevalence decreases with age ${ }^{3}$. The infection is associated to different clinic illness at genital lower tract being considered the commonest sexual transmitted viral infection ${ }^{1}$. Besides, the virus also induces persistent infection in the genital tract carrying abnormal epithelial changes which in few cases could progress from low grade dysplasia to cervical cancer ${ }^{39}$. If a persistent infection with oncogenic HPV precedes virtually all high-grade dysplasias or neoplasias, thus the persistence for high-risk HPV DNA is a marker for current or subsequent development of precursor lesions. So, sensitive screening techniques should be useful to detect HPV virus giving support to prevention of diseases.

HPV cervical disease screening is currently performed by cytology, colposcopy and HPV DNA testing. For genome detection, the hybrid capture is the most currently commercially available technique. It is easy to perform in clinical settings and is suitable for automation ${ }^{18}$. In the United States, HPV DNA Hybrid Capture II (HCII) testing was recently approved for use with the Pap test for women 30 years old and over ${ }^{12}$. However, this test does not recognize HPV types, but it is able to distinguish between groups of high and low risk types to cancer. Before the HCII introduction, in situ hybridization (ISH) was largely used to detect HPV infection in cervical smears and biopsies. Although useful $^{8,16}$ ISH has been replaced by hybrid capture and the polymerase

Financial support: CNPq, grant 470257-6 (NV)

(1) Departamento de Microbiologia e Parasitologia, Instituto Biomédico, UFF, Niterói, RJ, Brasil.

(2) Departamento de Epidemiologia e Bioestatística, Instituto da Saúde da Comunidade, UFF, Niterói, RJ, Brasil.

(3) Serviço de Patologia Cervical, Faculdade de Medicina, Universidade Federal Fluminense, Niterói, RJ, Brasil.

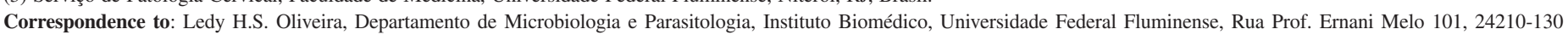
Niterói, RJ, Brasil. E-mail: mipledy@centroin.com.br 


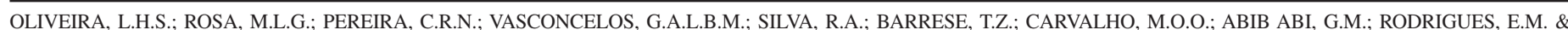
CAVALCANTI, S.M.B. - Human papillomavirus status and cervical abnormalities in women from public and private health care in Rio de Janeiro State, Brazil. Rev. Inst. Med. trop. S. Paulo, 48(5): 279-285, 2006.

chain reaction (PCR) for the great majority of epidemiologic and molecular studies. In fact, PCR has always proved to be a powerful and sensitive tool for detecting oncogenic HPV and to conduct epidemiological studies ${ }^{15,24,38}$.

Concerning cervical cancer, Brazilian mortality rates per 100000 women were 4.58 in $2003^{6}$. The average annual estimated rate for 2005 is 34.85 new cases per 10000 women in Rio de Janeiro, which is considered a high average when compared to some Brazilian Sates?

In Brazil, health care is universal. In attempt to control this disease, routine cytology has been used in screening programs for cervical cancer prevention. However, there is agreement about their relative low sensitivity ${ }^{14}$. Governmental programs mitigate the lack of high sensitivity by repeating tests every year or every three years for women having consecutive normal Pap exams ${ }^{5}$. Cervical cancer has a natural history with prolonged precancer stages that are easily detected and treated. However, women who attended public healthcare, are far from early detection and close surveillance following treatment for cervical cancer.

Despite the established causal association between infection and high-risk HPV leading to cancer has been clearly established, HPV testing is not part of current screening practice. The ideal screening police would be cytology and HPV testing for women over 30 years, as suggested by American Cancer Society ${ }^{43}$ but their cost-effectiveness, the lack of infrastructure and trained personnel for health centers make the start up of such preventive program very difficult.

In this present work two different female populations regarding health care systems were analyzed in the light of cervical abnormalities. Cytological diagnosis and HPV DNA testing by hybrid capture and polymerase chain reaction were performed. The performance of each HPV DNA assay was seen in the context of each set.

\section{MATERIAL AND METHODS}

Specimens - We studied 674 female patients attended at gynecological services from public and private health care systems from Rio de Janeiro State from 2000 to 2005. For better understanding, we described each series according to the methodology utilized.

Series 1 - Health insurance coverage population - A cross-sectional study population included 454 women enrolled from Laboratories Sérgio Franco from January to December, 2000. Women were referred to routine Papanicolaou exam at private clinics. If there was any abnormality they were guided to HPV detection. The cervical smears were collected by using a cervical cytobrush, and transported in Digene Specimen Transport Medium (Digene Diag, Md). Cytological test was developed and smears were classified based on Pap diagnosis group which was converted to Bethesda nomenclature ${ }^{10}$. Cervical lesions were classified as Normal, HPV infection (koilocytosis), ASCUS (atypical squamous cells of undetermined significance), low grade squamous intraepithelial lesions (LSIL-CIN I), high grade squamous intraepithelial lesions (HSIL - CIN II, III/ in situ carcinoma), and squamous invasive carcinoma (CA).

Hybrid capture II (HCII) - The assay kit detects low risk HPV types $6,11,42,43,44$ and high-risk types $16,18,31,33,35,39,45,51$,
52, 56, 58, 59, 68. Bound RNA-DNA hybrids were reacted with an alkaline phosphatase-conjugated antibody directed against the hybrids. A chemiluminescent compound, Lumi-Phos 530, was added as a substrate for alkaline phosphatase. The light produced by ensuing reaction was measured by a Luminometer and were expressed as relative light units (RLUs). As a negative control, sonicated herring sperm DNA in Digene transporting medium $(100 \mu \mathrm{g} / \mathrm{mL})$ was used. Triplicate specimens of HPV 16 or HPV 11 DNAs at $1.0 \mathrm{pg} / \mathrm{mL}$ served as the positive controls for high-risk and low-risk probes, respectively. Since the amount of the light produced by the hybrid capture assay is theoretically proportional to the amount of target HPV DNA, the results could be viewed as quantitative.

Series 2 - Public health care people - A cross-sectional study including 220 women was carried out from 2001 to 2005. They attended at the Service of Cervical Pathology of Hospital Universitário Antonio Pedro (HUAP), Universidade Federal Fluminense. Women participating in the study came directly to outpatient clinic of the Hospital or derived from public health services which provide cytological screening. These services were situated in poor neighbor cities which do not hold an adequate medical care. These women were enrolled for the study if had abnormal cytology. Colpocytology was performed at the first or subsequent visit to the Service. For women with high grade cervical cytology, biopsies were performed. Cervical lesions were classified as Normal, HPV infection (koilocytosis), ASCUS (atypical squamous cells of undetermined significance), low grade squamous intraepithelial lesions (LSIL-CIN I), high grade squamous intraepithelial lesions (HSIL - CIN II, III, in situ carcinoma), and squamous invasive carcinoma (CA). The Ethical Committee of Medicine College at the University approved the protocol for collection as well the informed consent.

DNA extraction - Samples were incubated for four hours at $50{ }^{\circ} \mathrm{C}$ in digestion buffer (10 mM Trishydrochloric acid pH 8.3, 1 mM EDTA $\mathrm{pH} 8.0, .5 \%$ Tween 20 , proteinase $\mathrm{K}$; final concentration of $400 \mu \mathrm{g} /$ $\mathrm{mL})$. Later, they were extracted with phenol-chloroform-isoamyl alcohol (25:24:1). DNA was precipitated with one-tenth volume of 0.3 M sodium acetate and three volumes of $100 \%$ ice-cold ethanol, washed with $70 \%$ ethanol, air-dried and suspended in $50 \mu \mathrm{L}$ of sterile water.

PCR procedure - MY09/11 consensus primers, which amplify 450bp (base pair) DNA sequences within the L1 region of HPV, were used to detect generic HPV DNA ${ }^{23}$. Amplification was carried out in $50 \mu \mathrm{L}$ of reaction mixture $(1 \mathrm{X}$ polymerase chain reaction [PCR] buffer, 200 $\mathrm{mM}$ dNTPs, $1.5 \mathrm{mM} \mathrm{MgCl} 2,50 \mathrm{pmol}$ of each primer, $0.25 \mathrm{U}$ unit of Taq polymerase, and $5 \mu \mathrm{L}$ of sample) with 35 cycles of amplification. Each cycle included a denaturation step at $94{ }^{\circ} \mathrm{C}$ for one minute, an annealing step at $55^{\circ} \mathrm{C}$ for two minutes, and a chain elongation step at $72{ }^{\circ} \mathrm{C}$ for two minutes using DNA Thermal Cycler (Perkin Elmer, CETUS). The beta-actin primers $(0.1$ pmol each $)$, which amplify a 330-bp region of the human DNA, were used as an internal control. Polymerase chain reaction products were analyzed on $1.3 \%$ agarose gel with ethidium bromide staining for visualization of DNA under ultraviolet light and their molecular weight was determined by comparison with a 100-bp DNA ladder.

HPV typing was done by PCR using primers from the E6 gene DNA sequences of HPVs 6, 11, 16, 18, 31, 33, 35 and $58^{31}$. These primers yielded 230, 89, 134, 119, 97, 132, 186, and 100-bp fragments, 


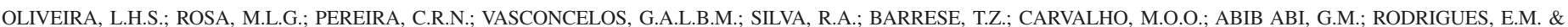

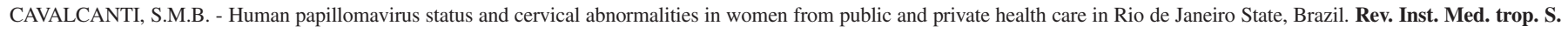
Paulo, 48(5): 279-285, 2006.

respectively. The PCR included 35 steps at $94{ }^{\circ} \mathrm{C}$ for 30 seconds, $60{ }^{\circ} \mathrm{C}$ for one minute, and $72{ }^{\circ} \mathrm{C}$ for one minute. Negative controls for background contamination did not add to the DNA template. The PCR run was completed by extension for 10 minutes at $72{ }^{\circ} \mathrm{C}$. After DNA extraction with phenol-chloroform-isoamyl alcohol, the PCR amplification of generic human papillomavirus was done. To avoid background contamination negative controls were performed without DNA template. The primers Ac1 and Ac2, specific for the amplification of a 330 base pairs (bp) fragment of the actin gene, were used as a sample quality control ${ }^{17}$.

Statistical analysis - The statistical significance of results was analyzed by using the $\mathrm{X}^{2}$ test for heterogeneity with Yates continuity correction. Fisher exact test and a Mantel-Haentzel procedure for trend were applied when appropriate. The significance level of tests (p) was set at 0.05 .

\section{RESULTS}

Series 1 - The average age of participants was 31.5 years, varying from 15 to 70 years. Most of women presented either normal epithelium $(40.7 \%)$ or benign cervical lesions $(52.5 \%)$. Few cases of premalignant lesions were detected (7.27\%) and no cancer cases were reported (Table 1). As shown in Table 2, HPV DNA prevalence is presented according to the available cytological diagnosis: the overall prevalence of HPV DNA in the studied group was $58.4 \%$ (265/454) ranging from $20.9 \%(41 / 196)$ in normal cytology to $90.4 \%$ (104/115) in LSIL. From the 265 HPV positive women, $25(9.4 \%)$ had low risk HPV DNA to cancer; 156 $(58.8 \%)$ had high risk HPV types and $84(31.6 \%)$ had both groups. About $90 \%$ of the women were infected by at least one high risk HPV type.

Different mean age distribution patterns were detected in HPV infected patients according to cytological diagnosis (Table 3). Normal group was significantly different when compared to HSIL group ( $\mathrm{p}<$ 0.0001 ). In the same way, most of women HPV infected had from 2130 years old $(47.5 \%)$. In this sample, the HPV infection decreased as the age increased (Table 4).
Series 2 - The eligible women aged from 14 to 82 years, mean age 38 years. They had low income status. In this series, we observed the reverse of the pattern described above for series 1 on several aspects. Normal epithelium was found in only $20 \%$ ( $p<0.001$ when compared to series 1) of these women while premalignant and malignant lesions reached $42.72 \%(\mathrm{p}<0.001)$ of the total sample. Out of 36 women (16.36\%) carried cervical cancer. ASCUS and LSIL prevalence were similar in both groups (Table 1).

HPV infection status was $77.3 \%$ (170/220) in this series. The overall prevalence was statistically higher than series $1(\mathrm{p}<0.001)$. With respect to HPV prevalence by mean age according the level of abnormality detected by cytology, we had to point the low mean age of the women carrying HSIL (36.2) and invasive cancer (50.9) (Table II). In a hallmark contrast with the series 1, a high HPV infection incidence was detected among all age groups (Table 4).

The HPV frequency ranges from $43.2 \%$ (19/44) in normal cervical epithelium to $94.4 \%$ (34/36) among cancer. HPV types detected in the series 2 were grouped in low and high risk types for standardizing the results (Table 2). Multiple infections (two or more HPV types) were detected in $15.8 \%$ (27/170) of HPV positive smears. Those caused by two low risk HPV types were only associated to benign abnormalities

Table 1

Prevalence of cytological diagnosis among series 1 and series 2 women

\begin{tabular}{llll}
\hline Cytology & $\begin{array}{l}\text { Series 1 } \\
\text { Number }(\%)\end{array}$ & $\begin{array}{l}\text { Series 2 } \\
\text { Number }(\%)\end{array}$ & $p$ \\
\hline Normal & $185(40.74)$ & $44(20.0)$ & $<0.001$ \\
HPV & $110(24.23)$ & $30(13.64)$ & 0.001 \\
ASCUS & $11(2.42)$ & $6(2.72)$ & 0.81 \\
LSIL & $115(25.33)$ & $46(20.91)$ & 0.2 \\
HSIL & $33(7.27)$ & $58(26.36)$ & $<0.001$ \\
CA & 0 & $36(16.36)$ & $<0.01$ \\
\hline TOTAL & $454(100)$ & $220(100)$ & \\
\hline
\end{tabular}

Table 2

Prevalences of HPV groups according to the cytological diagnosis by HCII among women of private health care and by PCR among women of public health care

\begin{tabular}{|c|c|c|c|c|c|c|c|}
\hline Cytology & Normal & HPV & ASCUS & LSIL & HSIL & $\mathrm{CA}$ & TOTAL \\
\hline \multicolumn{8}{|c|}{ Series 1} \\
\hline GRUPO A ${ }^{\mathrm{a}}$ & 7 & 8 & 0 & 10 & 0 & 0 & 25 \\
\hline GRUPO B ${ }^{\mathrm{b}}$ & 16 & 55 & 2 & 66 & 17 & 0 & 156 \\
\hline GRUPO $A+B^{c}$ & 15 & 29 & 1 & 28 & 11 & 0 & 84 \\
\hline Prevalence & $38(20.5 \%)$ & $92(83.6 \%)$ & $3(2.7 \%)$ & $104(90.4 \%)$ & $28(84.8 \%)$ & 0 & $265(58.4 \%)$ \\
\hline \multicolumn{8}{|c|}{ Series 2} \\
\hline Low $^{\mathrm{d}}$ risk & 5 & 5 & 1 & 8 & 1 & 1 & 21 \\
\hline Highe $^{\mathrm{e}}$ risk & 11 & 11 & 3 & 20 & 41 & 22 & 109 \\
\hline Mixed $^{\mathrm{f}}$ & 0 & 1 & 0 & 4 & 7 & 9 & 21 \\
\hline $\mathrm{U}$ & 3 & 6 & 0 & 3 & 5 & 2 & 19 \\
\hline Prevalence & $19(43.2 \%)$ & $23(76.7 \%)$ & $4(66.7 \%)$ & $35(78.3 \%)$ & $54(93.1 \%)$ & $34(94.4 \%)$ & $170(77.3 \%)$ \\
\hline
\end{tabular}

a Low risk HPV 6,11,42,43,44; ${ }^{b} \mathrm{High}$ risk HPV 16,18,31,33,35,39,45,51,52, 56,58,59,68; ${ }^{\mathrm{c}}$ Mixed infection (low+high risk HPV); ${ }^{\mathrm{d} L o w}$ risk HPV 6,11; ${ }^{\mathrm{e} H i g h}$ risk HPV $16,18,31,33,35,58$; Low and high risk types in mixed infection; U: undetermined types. 


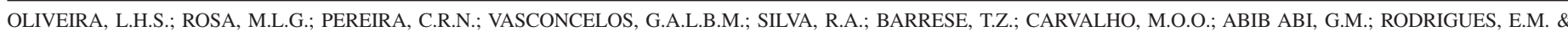
CAVALCANTI, S.M.B. - Human papillomavirus status and cervical abnormalities in women from public and private health care in Rio de Janeiro State, Brazil. Rev. Inst. Med. trop. S. Paulo, 48(5): 279-285, 2006.

Table 3

Mean age of HPV infected women from series 1 and 2 classified according to the cytological diagnosis

\begin{tabular}{lcccccc}
\hline Cytological diagnosis mean age & Normal & ASCUS & HPV & LSIL & HSIL & CA \\
\hline Series 1 & 27.0 & 32.5 & 27.9 & 34.8 & 49.3 & - \\
Series 2 & 37.4 & 29.7 & 45.5 & 35.3 & 36.2 & 50.9 \\
\hline
\end{tabular}

Table 4

HPV positivity according to the age of patients

\begin{tabular}{rccccccc}
\hline Age intervals & $11-20$ & $21-30$ & $31-40$ & $41-50$ & $51-60$ & $61-70$ & $>70$ \\
\hline Series $1(\mathrm{n}=265)$ & 50 & 126 & 56 & 24 & 7 & 2 & \\
$(\%)$ & 18.8 & 47.5 & 21.1 & 9.0 & 2.6 & 0.7 & \\
\hline Series 2 $(\mathrm{n}=170)$ & 8 & 46 & 54 & 35 & 16 & 6 & 5 \\
$(\%)$ & 4.7 & 27.0 & 31.7 & 20.5 & 9.4 & 3.5 & 2.9 \\
\hline
\end{tabular}

(3.5\% (6/170). Mixed infections (low and high risk HPV) were found in $12.5 \%(19 / 170)$ of the positive smears. Most of the HPV could be typed with the specific primers. However $11.1 \%$ (21/170) were not identified by using specific primers and they were referred as undetermined types.

\section{DISCUSSION}

This work does have limitations. We based our outcome in different HPV DNA technologies to compare different samples. The two methods have in general a good agreement, ranging from $76.5 \%{ }^{29}$ to $99.5 \%$. Since the goal of our work was to investigate two female populations attended at different health services, accessing different methodologies, this protocol might not affect our objective.

Both HPV tests had good agreement $(p<0.0001)$ with cytology and showed to be a useful tool when combined to cytology. Women from series 1 were tested for HPV infection by HCII. It is appropriated for screening infection because it detects a broad-spectrum of HPV types. This procedure makes it very expensive for low income people. By other side, HCII is not useful for genotyping and it cannot distinguish between persistent infection and re-infection ${ }^{20}$. So, mixed infection could not be detected in the series 1 . Besides, HPVs not yet typed cannot be identified by HCII therefore reducing the sensitivity of the test, differently from PCR using generic primers that can screen HPV by amplified conserved region.

The goal of our work was highlight disparities in cervical cancer incidence. Prevention throughout Papanicolaou exams is the hallmark in reducing cervical cancer. Although women from both samples were referred for previous abnormal cytology, people from series 1 have access to a treatment more easily and faster than women from series 2 before the development of pre-malignant lesions. Besides, many doctors guide their patients with minor cytological changes to HPV DNA testing. Women from series 2 have many barriers to complete the followup on time. Delays in care for abnormal cervical cytology can contribute to a later stage in diagnosis.

Significant cytological differences were seen between both groups. Normal and benign cases were incident in series 1 while pre-malignant lesions were found mainly in the series 2 (Table 1). Instead, HPV prevalence in normal cases were statistically higher than those from series $1(\mathrm{p}<0.001)$, indicating a higher exposure to HPV infection. Differences in HPV infection were found in ASCUS cases. The restricted number of cases in both series did not allow us evaluate this finding. Under the term ASCUS (atypical squamous cells of uncertain significance), cytologists referred all the inconclusive diagnostics. Not for sense, it is the most well-defined guideline for HPV DNA testing after equivocal Pap test results.

Private gynecologic clinics are not reference's guide to cervical pathology diagnosis. Therefore, the lack of this disease could be an expected result. However, gynecologic clinics might track high grade cervical lesions, which are precursor lesions normally asymptomatic. We have found $7.27 \%$ of these lesions from series 1 versus $26.36 \%$ from series 2. Besides, the laboratory Sergio Franco services a great network of clinics, then we could expect few cancer cases among women from series 1 , if they existed.

Women from this set have received a regular health care in private clinics and had higher education and economic level to get an annual screening test. If any abnormal cervical were recorded, complementary HPV DNA testing (HCII) were done at private laboratory diagnosis. In spite of cancer absence and reduced premalignant cases, $92 \%$ of the HPV positive patients carried high risk HPV types. Although HPV infection was higher in the series $2(\mathrm{p}<0.001)$, the rates of high risk HPV types were similar in both groups (Table 2).

The result is remarkable when compared to other series not randomly selected ${ }^{11,37}$. However, several works mention false-positive results seen in HCII test induced by crossing-reacting among highrisk probe cocktail with HPV types that are not represented in the probe mix $^{33,34,41}$. So, such high prevalence of oncogenic types may be overestimated. In spite some caveats, a panel of representative American experts recommended combined HCII and Pap screening to guide American clinicians. But these experts recognize that they may change as new data continues to evolve $\mathrm{e}^{42}$.

The mean ages in groups 1 and 2 were 31.5 and 38 years, respectively. Table 4 shows that HPV infected women from private clinics tended to 


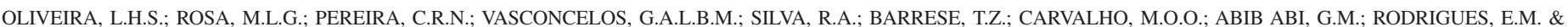

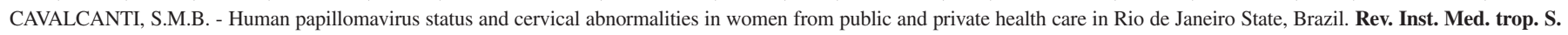
Paulo, 48(5): 279-285, 2006.

be younger than those attending at healthcare public services. According to several authors, transient infections are prevalent in young women ${ }^{13,25,26}$. So, virus clearance in people from series 1 could be as likely as HPV infection in the series 2 trended towards viral persistence.

Clearance is a common event compared to uncommon persistence. Genital infections tend to resolve spontaneously as do warts or low grade cervical lesions. A non-resolved problem related to natural history of HPV infection is the possibility of incomplete viral clearance that can result in viral latency ${ }^{40}$. Authors describe that for HPV, persistence is characterized by finding the same DNA type detected two or more times in over a period while latency implies that no HPV DNA is detectable by conventional molecular tests but that very small foci of cells maintain infection at low DNA copy numbers. Data about cervical cancer arising after a period of viral latency is largely unkown ${ }^{40}$. Recent studies suggest that viral load represent an important prognostic tool related to cancer establishment ${ }^{22,43}$. Our data showed that in series 1 , HPV prevalence declined with age $(66.3 \%$ in women under 30 years) what is consistent with viral transient infection. In series 2, HPV prevalence did never decrease (68\% in women up to 30 ) supporting not only the idea of viral persistence but also regional (sociodemographic) epidemiological variations in the same geographic area. This is an important data for further studies about clearance, persistence and latency. Studies with highly exposed prostitutes have shown decrease in HPV prevalence with ages, indicating loss of detectable HPV or type-specific immunity if reinfection occurs ${ }^{19}$.

Women from the series 2 were tested for DNA HPV by PCR, a high sensitive technique considered as the gold standard for HPV infection. However, there are several conditions, such as the DNA extraction procedures, differences for the detection of HPV infection in sampling methods and sample transport/storage, and especially the use of different polymerases for the PCR reactions that can affect test performance, as reported by MUNOZ et al. ${ }^{28}$. For HPV DNA detection, we used the protocol employing the consensus primers My09/11, directed to a highly conserved region of the $\mathrm{L} 1$ gene, capable of detecting all mucosal types ${ }^{23}$. Improvements developed for this technique increase widely the HPV detection in cervical cancer cases reaching nearly $96.6 \%$ of those cases ${ }^{27}$. In our study, by using this protocol, we detected HPV infection in $94.4 \%$ of the cancer cases. This average did not differ significantly from those found in worldwide publications $s^{3,27,28}$.

Multiple infections have been associated to promiscuous behavior ${ }^{36}$. For standard analysis between the two series, we considered coinfection at least one low and one high risk types in the same patient. This occurrence was observed in $31.6 \%$ (series 1) and $12.3 \%$ (series 2 ) of the women studied. Probably, in the HUAP patients, the small quantity of type specific primers restricted this finding. Our results are also underestimated in the series 1 due to incompatibility of HCII test to show more than one high risk type in the same smear. It is noteworthy that $26.4 \%$ of CA cases were co-infected, with a significant linear trend when we compared to remained cervical lesions.

Undetermined HPV types are a relative common finding in several works ${ }^{9,15,30,35}$. These authors could not type about 6-20\% of the HPV positive samples by restriction fragment length polymorphism (RFLP) detecting a broad range of HPV types. In series 2, we failed typifying $11.1 \%$ of the samples. Interestingly, the lowest rate of untyped HPV was found in cancer cases (6\%), showing that the high risk types 16 and 18 are responsible for most of them $(72.2 \%)$.

In this study, we focused on two female populations largely infected by high risk HPV types. However, cervical cancer was seen only in women from low income class. Besides persistent infection, cancer development results from socioeconomic inequalities. Income, education, domicile far from primary health care setting, transportation difficulty, and lack of health insurance coverage affect the access to appropriate early detection and treatment of cervical cancer and their precursor lesions. Hence, some of these factors account for the difference in mean age seen among two series. So, we highlighted the role of social inequalities in cervical linked to the HPV status. It is important to note that also in developed countries with decreased cervical cancer mortality, as in the United States, cytological screening has not been equally accessible to all subpopulations and incidence and mortality from cervical cancer are higher in ethnic minorities and poor women ${ }^{21}$. In fact, in this country, there is a decrease of more than half of the incident cases of invasive cervical cancer diagnosed in women who have not been adequately screened. PARIKH et al., 2003 $3^{32}$, surveying 57 case control studies, also emphasize the importance of the adequate cervical screening programmes in the high cervical cancer incidence observed in developing countries. In our country, although a national prevention policy exists, it performs inadequately. Therefore, a organized screening regional programme would be the only effective means in reducing the unequal burden of cervical cancer. The development of safe and effective vaccines against HPV also would diminish the toll of this disease that disproportionately affects poor women.

\section{RESUMO}

\section{Papilomavírus humano e anormalidades cervicais em mulheres do sistema de saúde privado e público no Estado do Rio de Janeiro, Brasil}

Este artigo analisa a infecção por HPV e anormalidades citológicas cervicais encontradas em pacientes atendidas em serviços ginecológicos dos sistemas de saúde público e privado do estado do Rio de Janeiro. O trabalho também avalia os testes utilizados para detecção de DNA do HPV em cada população estudada. Um grupo de 454 mulheres oriundas de serviços da rede privada de saúde foi testado por Captura do Híbrido II. Destas, 58,4\% apresentaram infecção por HPV e cerca de $90 \%$ delas estavam infectadas por HPV de alto risco. Este grupo, entretanto, apresentava poucos casos de lesões cervicais pré-malígnas e nenhum caso de câncer. Estudamos, também, 220 mulheres de baixo nível econômico atendidas no serviço de saúde pública que foram testadas para HPV pela reação da polimerase em cadeia utilizando-se os oligonucleotídeos My09/My11. A identificação dos tipos foi efetuada por amplificação com oligonucleotídeos específicos para a região E6 do genoma viral. A prevalência de HPV nesta população foi de $77.3 \%$, observando-se uma alta porcentagem de casos de neoplasias intraepiteliais cervicais de alto grau $(26,3 \%)$ e de carcinoma cervical invasivo (16,3\%). A infecção por HPV foi achada em, respectivamente, $93,1 \%$ e $94,4 \%$ destes casos. A média de idade em ambos os grupos era de 31,5 e 38 anos, respectivamente. Na série 1, a prevalência da infecção por HPV decresce com a idade, enquanto na série 2 ela não desaparece, dando suporte não só à idéia de persistência viral neste 


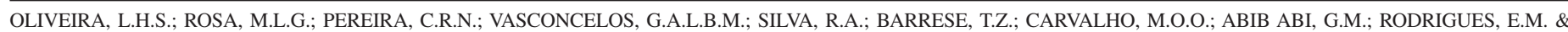
CAVALCANTI, S.M.B. - Human papillomavirus status and cervical abnormalities in women from public and private health care in Rio de Janeiro State, Brazil. Rev. Inst. Med. trop. S. Paulo, 48(5): 279-285, 2006.

grupo, mas também a variações epidemiológicas na mesma área geográfica. Diferenças significativas foram vistas nos dois grupos. Casos normais e benignos foram incidentes na série 1 , enquanto as lesões malígnas predominaram na série 2 . Ao contrário, casos normais infectados por HPV eram prevalentes na série $2(\mathrm{p}<0.001)$, indicando maior exposição ao vírus. Embora as mulheres de ambos os grupos tenham sido incluídas no estudo por apresentarem citologia anormal, evidências sócio-demográficas demonstram que mulheres da série 1 tem acesso mais fácil e rápido ao tratamento do que as mulheres da série 2 antes que as lesões pré-malígnas se desenvolvam. Estes resultados fornecem dados sobre o papel das desigualdades sociais associadas à infecção por HPV de alto risco na progressão do câncer cervical. Programas de prevenção abrangentes e o desenvolvimento de vacinas eficazes e seguras contra o HPV poderiam reduzir o tributo desta doença que afeta principalmente mulheres pobres.

\section{ACKNOWLEDGEMENTS}

To Trude Dimetz from Laboratório Sérgio Franco, for scientific assistance.

\section{REFERENCES}

1. ADIMORA, A.A.; HOLLI, H.A.; KING, H.K. \& SPARLING, P.F. - Sexually transmitted disease. In Epidemiology of sexually transmitted disease 2. ed. New York, McGrawHill International Editions, 1994. p. 1-9.

2. ANTONSSON, A.; ERFURT, C.; HAZARD, K. et al. - Prevalence and type spectrum of human papillomaviruses in healthy skin samples collected in three continents. J. gen. Virol., 84: 1881-1886, 2003.

3. BOSCH, F.X.; MANOS, M.M.; MUNOZ, N. et al. - Prevalence of human papillomavirus in cervical cancer: a worldwide perspective. International biological study on cervical cancer (IBSCC) study group. J. nat. Cancer Inst., 87: 796-802, 1995.

4. BOZZETTI, M.; NONNENMACHER, B.; MIELZINSKA, I.I. et al. - Comparison between hybrid capture II and polymerase chain reaction results among women at low risk for cervical cancer. Ann. Epidem., 10: 466, 2000.

5. BRASIL. MINISTÉRIO DA SAUDE, INSTITUTO NACIONAL DO CÂNCER Programa Nacional do controle de câncer do colo de útero e de mama, 2003. http://www.inca.gov.br/

6. BRASIL. MINISTÉRIO DA SAUDE, INSTITUTO NACIONAL DO CÂNCER Estimativa de incidência e mortalidade por câncer no Brasil, 2003. http:// www.inca.org.br

7. BRASIL. MINISTÉRIO DA SAÚDE, INSTITUTO NACIONAL DO CÂNCER Estimativa de incidência e mortalidade por câncer no Brasil, 2005. http:// www.inca.org.br

8. BRUCK, L.R.; ZEE, S.; POULOS, B.; CARROLL, D. \& ABADI, M. - Detection of cervical human papillomavirus infection by in situ hybridization in fetuses from women with squamous intraepithelial lesions. J. low. genit. Tract Dis., 9: 114-117, 2005 .

9. CÂMARA, G.N.L.; CERQUEIRA, D.M.; OLIVEIRA, A.P.G. et al. - Prevalence of human papillomavirus types in women with pre-neoplastic and neoplastic cervical lesions in the Federal District of Brazil. Mem. Inst. Oswaldo Cruz, 98: 879-883, 2003.

10. CARVALHO, M.O.O.; ALMEIDA, R.W.; LEITE, F.M.S. et al. - Detection of human papillomavirus DNA by the hybrid capture assay. Braz. J. infect. Dis., 7: 121-125, 2003.
11. DALSTEIN, V.; RIETHMULLER, D.; PRETET, J.L. et al. - Persistence and load of high-risk HPV are predictors for development of high-grade cervical lesions: a longitudinal French cohort study. Int. J. Cancer, 106: 396-403, 2003.

12. DIGENE CORPORATION PRESS RELEASE - Digene high-risk HPV DNA test approved by the FDA for adjunctive screening in women age 30 and older. Gaithersburg, Md, USA, 2003.. Available at: http: //www.digene.com/corporate01/ press_releases/prelease_frame.html.

13. EVANDER, M.; EDLUND, K.; GUSTAFSSON, A. et al. - Human papillomavirus infection is transient in young women: a population-based cohort study. $\mathbf{J}$. infect. Dis., 171: 1026-1030, 1995.

14. FRANCO, E.L. - Primary screening of cervical cancer with human papillomavirus test. J. nat. Cancer Inst. Monogr., 31: 89-96, 2003.

15. FRANCO, E.L.; VILLA, L.L.; SOBRINHO, J.P. et al. - Epidemiology of acquisition and clearance of cervical human papillomavirus infection in women from a high-risk area for cervical cancer. J. infect. Dis., 180: 1415-1423, 1999.

16. FUJII, T.; MASUMOTO, N.; SAITO, M. et al. - Comparison between in situ hybridization and real-time PCR technique as a means of detecting the integrated form of human papillomavirus 16 in cervical neoplasia. Diagn. Molec. Path., 14: 103-108, 2005.

17. GALL, K.; PAVICIC, D.; PAVELIC, J.; AUDY-JURKOVIC, S. \& PAVELIC, K. - PCR amplification of DNA from stained cytological smears. J. clin. Path., 46: 378-379, 1993.

18. IFTNER, T. \& VILLA, L.L. - Human papillomavirus technology. J. nat. Cancer Inst. Monogr., 31: 80-88, 2003.

19. KJAER, S.K.; SVARE, E.I.; WORM, A.M. et al. - Human papillomavirus infection in Danish female sex workers. Decreasing prevalence with age despite continuously high sexual activity. Sex. transm. Dis., 27: 438-445, 2000.

20. KJAER, S.K.; VAN DEN BRULE, A.J.C.; PAULL, G. et al. - Type specific persistence of high risk human papillomavirus (HPV) as indicator of high grade cervical squamous intraepithelial lesions in young women: population based prospective follow-up study. Brit. med. J., 325: 572-576, 2002.

21. LAWSON, H.W.; LEE, N.C.; THAMES, S.F.; HENSON, R. \& MILLER, D.S. - Cervica cancer screening among low-income women: results of a national screening program, 1991-1995. Obstet. Gynecol., 92: 745-752, 1998.

22. LEFEVRE, J; HANKINS, C; MONEY, D; RACHLIS, A. et al. - Human papillomavirus type 16 viral load is higher in human immunodeficiency virus-seropositive women with high-grade squamous intraepithelial lesions than in those with normal cytology smears. J. clin. Microbiol., 42: 2212-2215, 2004.

23. MANOS, M.M.; TING, Y.; WRIGHT, D.K. et al. - - Use of polymerase chain reaction amplification for detection of genital papillomavirus. Cancer Cells, 29: 20-27, 1989.

24. MAO, C.; BALASUBRAMANIAN, A. \& KOUTSKY, L.A. - Should liquid-based cytology be repeated at the time of colposcopy? J. low. genit. Tract. Dis., $9: 82-88$, 2005

25. MOSCICKI, A.B.; SHIBOSKI, S.; BROERING, J. et al. - The natural history of human papillomavirus infection as measured by repeated DNA testing in adolescent and young women. J. Pediat., 132: 277-284, 1998.

26. MOSCICKI, A.B.; SHIBOSKI, S.; HILLS, N.K. et al. - Regression of low-grade squamous intra-epithelial lesions in young women. Lancet, 364: 1678-1683, 2004.

27. MUÑOZ, N. - Human papillomavirus and cancer: the epidemiological evidence. J. clin. Virol, 19: 1-5, 2000.

28. MUÑOZ, N.; BOSCH, F.X.; SANJOSÉ, S. et al. - Epidemiologic classification of human papillomavirus types associated with cervical cancer. New Engl. J. Med., 348: 518$527,2003$. 


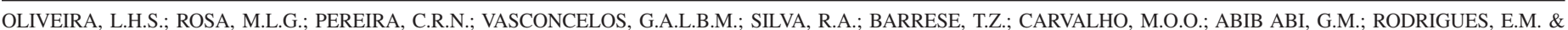

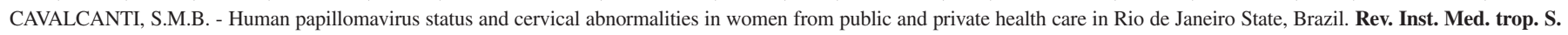
Paulo, 48(5): 279-285, 2006.

29. NONOGAKI, S.; WAKAMATSU, A.; LONGATTO FILHO, A. et al. - Hybrid capture II and polymerase chain reaction for identifying HPV infections in samples collected in a new collection medium: a comparison. Acta cytol. (Philad.), 48: 514-520, 2004.

30. NORONHA, V.; MELLO, W.; VILLA, L. et al. - Papilomavírus humanos associados a lesões de cérvice uterina. Rev. Soc. bras. Med. trop., 32: 235-240, 1999.

31. OLIVEIRA, L.H.S.; RODRIGUES, E.V.; LOPES, A.P.S.; FERNANDEZ, A.P. \& CAVALCANTI, S.M. - HPV 16 detection in cervical lesions, physical state of viral DNA and changes in p53 gene. São Paulo med. J., 121: 67-71, 2003.

32. PARIKH, S.; BRENNAN, P. \& BOFFETTA, P. - Meta-analysis of social inequality and the risk of cervical cancer. Int. J. Cancer, 105: 687-681, 2003.

33. PEYTON, C.L.; GRAVITT, P.E.; HUNT, W.C. et al. - Determinants of genital human papillomavirus detection in a US population. J. infect. Dis., 183: 1554-1564, 2001.

34. PEYTON, C.L.; SCHIFFMAN, M.; LORINCZ, A.T. et al. - Comparison of PCR- and hybrid capture-based human papillomavirus detection systems using multiple cervical specimen collection strategies. J. clin. Microbiol., 36: 3248-3254, 1998.

35. RABELO-SANTOS, S.H.; ZEFERINO, L.; VILLA, L.L. et al. - Human papillomavirus prevalence among women with cervical intraepithelial neoplasia III and invasive cervical cancer from Goiania, Brazil. Mem. Inst. Oswaldo Cruz, 98: 181-184, 2003.

36. REID, R.; GREENBERG, M.; JENSON, A.B. et al. - Sexually transmitted papillomavirus infection. I. The anatomic distribution and pathologic grade of neoplastic lesions associated with different viral types. Amer. J. Obstet. Gynec., 156: 212-222, 1987.
37. ROTELI-MARTINS, C.M.; PANETTA, K.; ALVES, V.A. et al. - Cigarette smoking and high-risk HPV DNA as predisposing factors for high-grade cervical intraepithelial neoplasia (CIN) in young Brazilian women. Acta obstet. gynec. scand., 77: 678$682,1998$.

38. SCHADENDORF, D.; TIEDEMANN, K.H.; HAAS, N. \& CZARNETZKI, B.M. Detection of human papillomaviruses in paraffin-embedded condylomata acuminata-comparison of immunohistochemistry, in situ hybridization, and polymerase chain reaction. J. invest. Derm., 97: 549-554, 1991.

39. SCHIFFMAN, M. \& CASTLE, E. - Human papillomavirus: epidemiology and public health. Arch. Path. Lab. Med., 127: 930-934, 2003.

40. SCHIFFMAN, M. \& KJAER, S.K. - Natural history of anogenital human papillomavirus infection and neoplasia. J. nat. Cancer Inst. Monogr., 31: 14-19, 2003.

41. VERNON, S.D.; UNGER, E.R. \& WILLIAMS, D. - Comparison of human papillomavirus detection and typing by cycle sequencing, line blotting, and hybrid capture. J. clin. Microbiol., 38: 651-655, 2000.

42. WRIGHT Jr., T.C.; SCHIFFMAN, M.; SOLOMON, D. et al. - Interim guidance for the use of human papillomavirus DNA testing as an adjunct to cervical cytology for screening. Obstet. Gynec., 103: 304-309, 2004.

43. WU, Y.; CHEN, Y.; LI, L. et al. - Associations of high-risk HPV types and viral load with cervical cancer in China. J. clin. Virol., 35: 264-269, 2006.

Received: 29 August 2005

Accepted: 14 June 2006 